\title{
Inhibition of Lipolysis by Agents Acting Via Adenylate Cyclase in Fat Cells from Infants and Adults
}

\author{
CLAUDE MARCUS. TOMAS SONNENFELD, BENGT KARPE, PER BOLME, AND PETER ARNER
}

\begin{abstract}
Departments of Pediatrics [C.M., P.B.], Medicine [P.A.], Surgery [T.S.], and the Research Center [P.A.], Huddinge University Hospital and the Department of Pediatric Surgery [B.K.J, St Görans Hospital, Karolinska Institute, Stockholm, Sweden
\end{abstract}

\begin{abstract}
The in vitro lipolytic effect of catecholamines is poor during infancy because of enhanced $\alpha_{2}-$ adrenoceptor activity. The mechanisms behind this were investigated in isolated fat cells obtained from 1- to 4-moold infants and from adults. The cells were incubated with agents that inhibit lipolysis through distinct receptors coupled to adenylate cyclase via the inhibitory GTP binding coupling protein, $\mathbf{G}_{\mathbf{i}}$. The sensitivity to the $\alpha_{2}$-adrenoceptor agonist clonidine was 14 times higher in the infant group as compared to the adults, whereas that to an adenosine analogue was 14 times lower. The sensitivities to prostaglandin $\mathbf{E}_{2}$ and nicotinic acid were similar in both age groups. Preincubation of the adipocytes with pertussis toxin abolished the antilipolytic effects of all agents. The density of $\alpha_{2}$-adrenoceptor binding sites determined with $\left[{ }^{3} \mathrm{H}\right]$ yohimbine was increased by about $25 \%$ in the infants. In conclusion, the antilipolytic sensitivity of adenosine and $\alpha_{2}$-adrenoceptors develops separately and may play different roles in the regulation of lipolysis in man. Furthermore, the enhanced $\alpha_{2}$-adrenoceptor sensitivity during infancy seems at least in part to be due to an increase in the number of receptors. (Pediatr Res 26:255-259, 1989)
\end{abstract}

\section{Abbreviations}

$\mathrm{G}_{\mathrm{i}}$, inhibitory GTP binding coupling protein

PGE, prostaglandin $\mathrm{E}_{2}-\alpha$

PIA, $\mathbf{N}^{6}$-phenylisopropyl adenosine

$\mathrm{PT}$, pertussis toxin

Catecholamines play a central role in the regulation of lipolysis in adult human adipocytes since they are the only hormones with an acute stimulatory effect on lipolysis in these cells. This stimulation is mediated via $\beta$-adrenoceptors. However, human fat cells differ from adipocytes in most other species, such as the rat, because they also have antilipolytic $\alpha_{2}$-adrenoceptors $(1,2)$. Thus, in man the net effect of catecholamines on lipolysis depends on the balance between lipolytic $\beta$-adrenoceptors and antilipolytic $\alpha_{2}$-adrenoceptors.

Received January 17, 1989; accepted April 26, 1989.

Correspondence Claude Marcus, M.D., Department of Pediatrics, Huddinge Hospital, S-141 86 Huddinge, Sweden.

Supported by grants from the Swedish Society of Medicine, the Swedish Medical Research Council (19x 01034), Karolinska Institute, The Golje Memorial, the Samariten, the Helge Ax:son Johnsson, the Hedlund, the Magnus Bergvall, the Groschinsky, the Nordic Insulin Foundations, and the Society for Aged Female Servants.
The normal development of catecholamine-induced lipolysis was recently investigated in human fat cells $(3,4)$. In neonates the lipolytic effect of endogenous catecholamines was very poor and not significant. During the first year of life the catecholamine-induced lipolysis increased gradually up to adult levels. The poor lipolytic effect seemed to be due mainly to an enhanced $\alpha_{2}$-adrenoceptor activity; the lipolytic $\beta$-adrenoceptor-mediated effect was not changed (3). The mechanisms behind the agedependency of $\alpha_{2}$-adrenoceptor activity are not clear. In theory, the adrenoceptor, the GTP-sensitive coupling protein $\mathrm{G}_{\mathrm{i}}$ and/or the catalytic component of adenylate cyclase may be involved $(5,6)$.

Prostaglandins of the E-type, adenosine and nicotinic acid are also hormones or paraendocrine substances which are able to inhibit adipocyte lipolysis via the same postreceptor pathway as catecholamines (5). The inhibition of lipolysis is mediated by different hormone-specific cell surface receptors, but they all seem to act at least in part through $G_{i}$, which inhibits adenylate cyclase activity $(5,6)$. Thus, an important question is whether the antilipolytic effects of these endogenous adenylate cyclase inhibitors are regulated and develop in a similar or in a different fashion.

In our study we investigated the normal development of the adipocyte response to these antilipolytic hormones by comparing the effects of clonidine ( $\alpha_{2}$-adrenoceptor agonist), PGE, nicotinic acid, and the adenosine analogue PIA on isolated fat cells from infants 1-4 mo old and adults in the absence or the presence of PT that abolishes the inhibitory function of $G_{i}(7)$. This was done by means of a previously developed sensitive glycerol assay that makes possible detailed pharmacologic studies of lipolysis in microsamples of human adipocytes (8). The properties of the $\alpha_{2}$ adrenoceptor binding on intact adipocytes from infants and adults were also investigated by means of an $\alpha_{2}$-adrenoceptor assay for isolated fat cells (9).

\section{MATERIALS AND METHODS}

Subjects. The study comprised 25 infants aged 1-4 mo (10 \pm $3 \mathrm{wk}$; mean $\pm \mathrm{SD})$ and 20 adults between 23 and $46(36 \pm 8)$ y of age. Both male and female subjects were investigated. All subjects underwent inguinal hernia operations. They were otherwise healthy and of normal wt. After an overnight fast, anesthesia was induced with thiopental sodium and maintained with fentanyl and a mixture of oxygen and nitrous oxide. Pancurone was given as a muscle-relaxing agent.

The antilipolytic effects of clonidine, PGE, PIA and NiAc were studied in adipose tissue from 10 infants $(9 \pm 3 \mathrm{wk})$ and nine adults $(33 \pm 6 y)$. Due to the small amounts of adipose tissue obtained, especially from the infants, it was not always possible to test all agents in each subject. In five of 10 infants and seven 
of nine adults all four agents were tested. The $\alpha_{2}$-adrenoceptor binding studies were performed in adipose tissue from seven infants $(9 \pm 3 \mathrm{wk})$ and five adults $(39 \pm 7 \mathrm{y})$ and the effects of pertussis toxin on lipolysis was tested in six infants $(11 \pm 2 \mathrm{wk})$ and six adults $(37 \pm 8 \mathrm{y})$. There were no significant differences between the infant or adult subgroups as regards weight, sex distribution or fat cell size. The study was approved by the Ethics Committee of the Karolinska Institute.

Isolation of adipocytes and determination of lipolysis and fatcell size. Subcutaneous adipose tissue (100-300 mg) was excised from the surgical incision at the start of the operation. Isolated adipocytes were prepared by Rodbell's method (10) and incubated as described previously (11). In brief, fat cells were isolated by collagenase digestion and incubated in duplicate for $2 \mathrm{~h}$ at $37^{\circ} \mathrm{C}$ in Krebs-Ringer phosphate buffer containing albumin $(40$ $\mathrm{g} / \mathrm{L})$, glucose $1 \mathrm{~g} / \mathrm{L})$, and ascorbic acid $(0.1 \mathrm{~g} / \mathrm{L})$, with air as the gas phase. The final fat-cell concentration was $1 \%$ (vol/vol). At the end of the incubation an aliquot of the medium was removed for the analysis of glycerol release, which was used as an index of lipolysis and was determined by a sensitive kinetic bioluminescence method (8). Fat cell diameter was measured during direct microscopy and mean fat cell volume and fat cell surface area were calculated as described in detail previously $(12,13)$.

Determination of antilipolytic effects. To study the antilipolytic effects, lipolysis was induced with $10^{-9} \mathrm{~mol} / \mathrm{L}$ of isoprenaline. This concentration was chosen because in previous experiments (3) it had been found to induce half-maximum stimulation of lipolysis in both infants and adults. It has previously been demonstrated that human fat-cell suspensions may contain endogenous adenosine which sometimes produces marked effects on lipolysis in human fat cells (14). However, in our incubation system, the influence of endogenous adenosine on lipolysis has been minimal $(3,15)$ and it is recently reported that extracellular adenosine in fat cell suspensions accumulates predominantly as a result of cell lysis (16). In any case, adenosine deaminase $1 \mathrm{U} /$ $\mathrm{mL}$ ) was added to the incubation medium to remove extracellular adenosine. Clonidine, PIA, PGE, and nicotinic acid were added in the concentration range of $10^{-15}-10^{-5} \mathrm{~mol} / \mathrm{L}$.

Effects of $P T$. Fat cells were preincubated for $2 \mathrm{~h}$ with or without PT $(2 \mu \mathrm{g} / \mathrm{mL})$ at $37^{\circ} \mathrm{C}$ in the same basal medium, as described above. The cells were thereafter washed and incubated with or without lipolytic and antilipolytic agents as described above. Before use, pertussis toxin was activated, as described by Kather et al. (17). In methodologic studies it was observed that pertussis toxin altered lipolysis in human fat cells with a lag period of 90-120 min, which confirms previous results (17).

$\alpha$-2-adrenoceptor binding experiments. $\alpha_{2}$-Adrenoceptor binding experiments were mainly performed by the method of Engfeldt et al. (9). The modification was a reduction of both the fat cell concentration and the incubation volume. Briefly, fat cells $\left(7 \% \mathrm{vol} / \mathrm{vol}\right.$ ) were incubated at $37^{\circ} \mathrm{C}$ for $15 \mathrm{~min}$ in Krebs ringer phosphate buffer ( $\mathrm{pH} 7.4$ ) supplemented with $0.1 \mathrm{mg} / \mathrm{mL}$ of ascorbic acid, $5 \mathrm{~g} / \mathrm{L} \mathrm{BSA}$ and glucose $(5 \mathrm{mmol} / \mathrm{L})$. [ ${ }^{3} \mathrm{H}$ ]yohimbine was used as radioligand. This ligand binds to a single homologous binding site in human fat cells (9). Nonspecific binding (about $30 \%$ of total binding) was subtracted from the total binding and was determined by incubating the adipocytes with phentolamine $(1 \mu \mathrm{mol} / \mathrm{L})$ or clonidine $(100 \mu \mathrm{mol} / \mathrm{L})$ in combination with the radioligand. All incubations were carried out in duplicate.

Expression and analysis of results. Lipolysis was expressed per unit of cell surface area, which makes it possible to compare lipolysis in fat cells of different sizes. Changes in lipolysis, which merely reflect variations in fat cell size, are avoided by this expression $(3,5)$. To study the sensitivity of the cells to the substances studied, the dose-response curves were plotted as a percentage of the maximal inhibitory effect. The latter was calculated as glycerol release with only isoprenaline and adenosine deaminase present in the medium, minus glycerol release at the maximum effective inhibitory concentration of the sub- stance. The concentration of agonist that produced $50 \%$ of the maximum effect $\left(\mathrm{ED}_{50}\right)$ was calculated graphically from the individual dose-response curves.

For the same reasons as mentioned above, the estimates of $\left[{ }^{3} \mathrm{H}\right]$ yohimbine binding sites are expressed per unit of cell surface area. The $\left[{ }^{3} \mathrm{H}\right]$ yohimbine saturation binding data were analyzed according to the Scatchard's method (18).

Chemicals. Clonidine, nicotinic acid, PGE, and PIA were obtained from Sigma Chemical Co., St. Louis, MO. The collagenase was prepared from clostridium histolyticum and was of Sigma type 1. Dialyzed BSA (fraction V) was purchased from the Armour Pharmaceutical Co, Eastbourne, England. The PT came from List Biological Laboratories, Campbell, CA and ADA from Boehringer Mannheim, FRG. The same batches of collagenase, albumin and pertussis toxin were used in all experiments. $\left.{ }^{3} \mathrm{H}\right]$ yohimbine (sp act $82.6 \mathrm{Ci} / \mathrm{mmol}$ ) was purchased from New England Nuclear Corporation, Boston, MA and phentolamine was a gift from Ciba-Geigy, Gothenburg, Sweden. All other chemicals were of the highest grade of purity commercially available.

Statistical methods. The values presented are the means and the SEM. The statistical methods used are the Student's unpaired $t$ test, Mann-Whitney's nonparametrical test, and linear regression analysis.

\section{RESULTS}

Fat cell size, basal and isoprenaline-induced lipolysis. The mean fat cell volume was $185 \pm 32 \mathrm{pL}$ in the infant group and $567 \pm 95 \mathrm{pL}$ in the adult group. Thus, the fat cells from adults were three times larger than the fat cells from the infants. This confirms numerous previous studies.

Unstimulated (i.e. basal) lipolysis showed no difference between adults and infants, i.e. in the adults it was $1.5 \pm 0.3$ and in the infants $1.4 \pm 0.2 \mu \mathrm{mol}$ glycerol $/ 2 \mathrm{~h} / \mu \mathrm{m}^{2} \times 10^{-11}$. To study the antilipolytic effects, lipolysis was induced with a submaximal effective concentration of isoprenaline $\left(10^{-9} \mathrm{~mol} / \mathrm{L}\right)$. With this isoprenaline concentration, the rates of lipolysis in infants and adults were almost identical, i.e. $7.8 \pm 1.2$ and $7.2 \pm 0.8 \mu \mathrm{mol}$ glycerol $/ 2 \mathrm{~h} / \mu \mathrm{m}^{2} \times 10^{-11}$, respectively. The data with basal and isoprenaline-stimulated lipolysis confirm previous results $(3,4,15)$.

Antilipolytic effects of clonidine, PIA, nicotinic acid and PGE. Figure 1 shows the maximum inhibitory response of the drugs

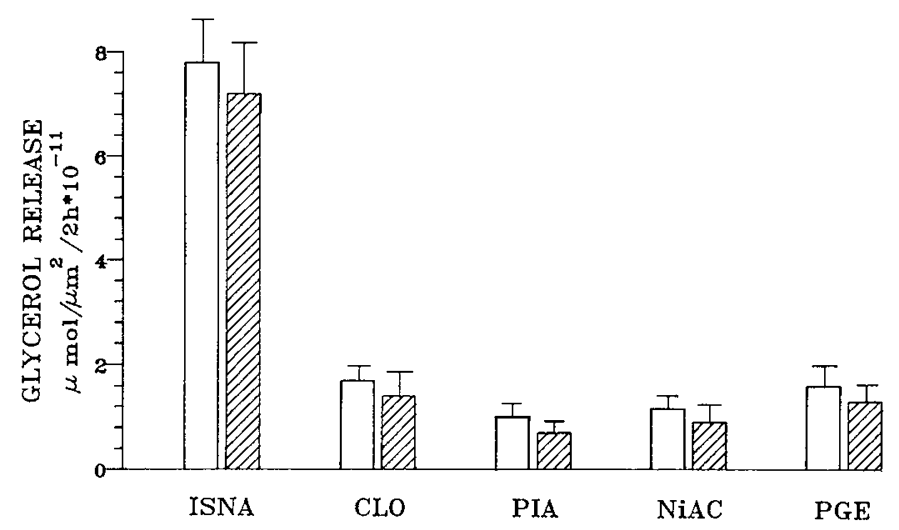

Fig. 1. Antilipolytic effect of agents acting via adenylate cyclase. Adipocytes from 10 infants (open bars) and nine adults (hatched bars) were incubated with increasing concentrations of clonidine (CLO), PIA, nicotinic acid $(N i A C)$ and PGE with isoprenaline $\left(I S N A, 10^{-9} \mathrm{~mol} / \mathrm{L}\right)$ as the lipolytic agent. Adenosine deaminase $(1 \mathrm{U} / \mathrm{ml})$ was also present in the incubation medium. Glycerol release without addition of antilipolytic agent and in the presence of maximum effective concentrations of the various antilipolytic agents is shown. Values are means \pm SE. The number of infant/adult subjects investigated for each agent were: clonidine seven/nine, PIA six/nine, PGE seven/eight, and nicotinic acid seven/seven. 
in infants and adults. There was no significant difference between infants and adults regarding the maximum response to any of the drugs studied. This was true whether inhibition was expressed in absolute values, as in Figure 1, or whether it was expressed as a percentage of the isoprenaline-induced lipolysis (graph not shown). The maximal effect of the antilipolytic agents was an 80-90\% inhibition of isoprenaline-induced lipolysis.

To study the sensitivity of the antilipolytic drugs, the doseresponse curves were plotted as a percentage of the maximum inhibition. Figure 2 shows the mean dose-response curves of clonidine and PIA in infants and adults. The sensitivity to clonidine was much greater in the infants than in the adults (Fig. $2 A$ ). The mean of the individual $\mathrm{ED}_{50}$ values for clonidine was about $6 \mathrm{nmol} / \mathrm{L}$ in the infant group and 84 in the adult group (Fig. 3). thus, it was 14 times lower $(p<0.01)$ in the infants than among the adults.

The findings for PIA sensitivity (Fig. $2 B$ ) differed completely from those with clonidine sensitivity. PIA was a much more potent antilipolytic drug when incubated with fat cells from adults than when incubated with fat cells from infants. The mean of the individual $\mathrm{ED}_{50}$ values was 14 times lower $(p<0.05)$ in the adult group than in the infant group $(0.05$ and $0.7 \mathrm{nmol} / \mathrm{L}$, respectively) (Fig. 3).

The mean dose-response curves for nicotinic acid and PGE were almost the same in infants and in adults (Fig. $2 \mathrm{C}$ and D). The individual $\mathrm{ED}_{50}$ values of nicotinic acid were also practically the same in infants and adults (Fig. 3). There were considerable interindividual differences between the $\mathrm{ED}_{50}$ values for PGE in both the infant and the adult groups (Fig. 3). However, the means of the individual $\mathrm{ED}_{50}$ values for PGE did not differ between the infants and adults.

To investigate whether there was a relationship between the sensitivities for the different inhibitors in the same individual,
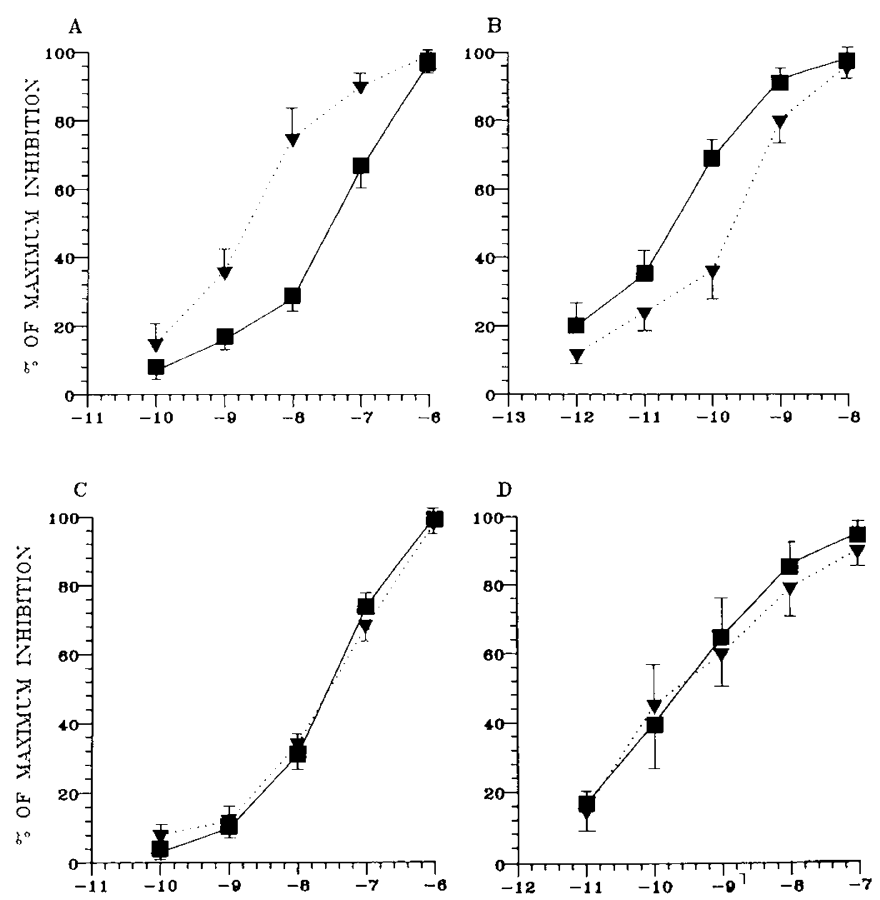

LOG INHIHITOR CONCENTRATION, MOL/1

Fig. 2. Sensitivity of clonidine- and PIA-induced inhibition of lipolysis. The dose-response curves for clonidine $(A)$, PIA $(B)$, nicotinic acid $(C)$, and PGE $(D)$ from the investigation in Figure $I$ were plotted as the percentage of the maximal inhibitory effect. The latter was calculated as the glycerol release with isoprenaline and adenosine deaminase present in the medium, minus the glycerol release at the maximum effective inhibitory concentration of the drug. Infants $=$ triangles, dotted line and adults $=$ squares, solid line . correlations between individual $\mathrm{ED}_{50}$ values of the antilipolytic agents were determined. No such relationship between the agents was found in infants or adults $(r<0.2)$.

The importance of the $G_{i}$ protein for the antilipolytic effects of clonidine and PIA was investigated. Adipocytes from infants and adults were preincubated with or without PT and thereafter with isoprenaline \pm clonidine or PIA. The glycerol release from the PT pretreated cells was slightly higher $(8.8 \pm 1.8$ in the infants, $7.5 \pm 1.9$ in the adults) than in the cells with isoprenaline and ADA-stimulated lipolysis alone $(7.0 \pm 0.8$ in the infants and

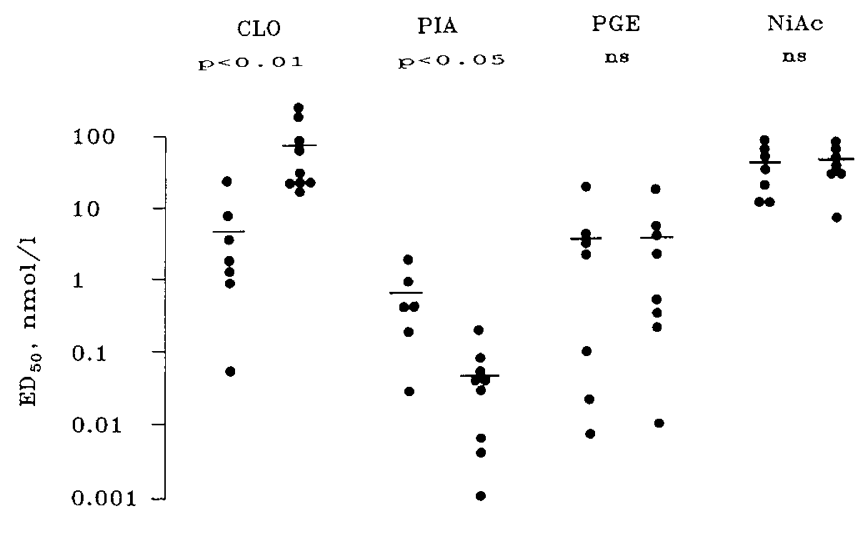

Fig. 3. Concentration of drugs giving half-maximal inhibition of lipolysis $\left(E_{50}\right)$. The experiments in Figure 2 were used to calculate the $\mathrm{ED}_{50}$ values for clonidine (CLO), PIA, PGE, and nicotinic acid (NiAC) in infants $(I n)$ and adults $(A d)$ from each individual dose-response curve. The statistical difference was tested using the Mann-Whitney's nonparametrical test. $n s$, not significant.
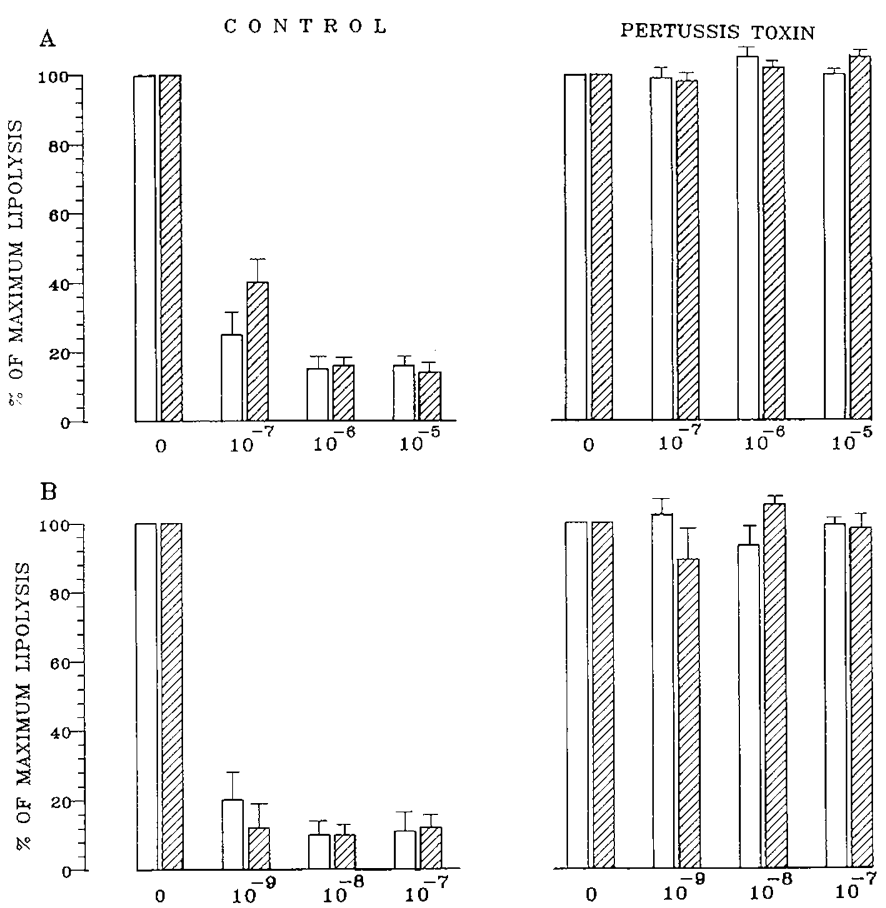

INHIBITOR CONCENTRATION, MOL/1

Fig. 4. Effect of pretreatment of adipocytes with PT on clonidineand PIA-induced inhibition of lipolysis. Fat cells from three infants (open bars) and three adults (hatched bars) were preincubated for $2 \mathrm{~h}$ with or without $2 \mu \mathrm{g} / \mathrm{mL}$ of PT. Thereafter fat cells were incubated with isoprenaline and adenosine deaminase together with increasing concentrations of clonidine $(A)$ or PIA $(B)$, as described in Figure 1. Values are in percent of isoprenaline-induced lipolysis (mean \pm SE). 


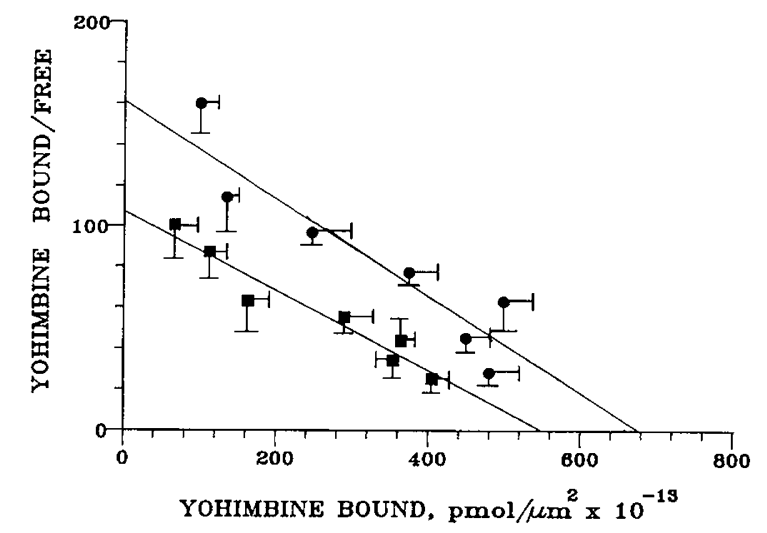

Fig. 5. $\left[{ }^{3} \mathrm{H}\right]$ yohimbine binding to adipocytes from infants and adults. Adipocytes from infants and adults were incubated with increasing concentrations of $\left[{ }^{3} \mathrm{H}\right]$ yohimbine. The Scatchard plot is shown. The values are means of seven infants and five adults. Circles, infants. Squares, adults. The equations for the regression lines are: $\mathrm{Y}=-0.23 \mathrm{X}$ $+155 ; r=0.92$ in infants and $\mathrm{Y}=-0.19 \mathrm{X}+104 ; r=0.97$ in adults.

$6.5 \pm 1.2$ in the adults). As indicated in Figure 4, no antilipolytic effect of PIA or clonidine was detected in infants or in adults when the cells were pretreated with PT. Similar results were obtained with PGE and nicotinic acid (data not shown). However, insulin inhibited lipolysis markedly in fat cells that were exposed to pertussis toxin in infants and adults (data not shown). This indicates that the toxin did not cause irreversible stimulation of lipolysis.

$\alpha_{2}$-adrenoceptor binding. The $\left[{ }^{3} \mathrm{H}\right]$ yohimbine Scatchard curves for adipocytes from infants and adults are shown in Figure 5. The slopes were almost identical in both groups, i.e. there were no significant differences in $\mathrm{k}_{\mathrm{d}}$ values $\left(4.2\right.$ and $5.2 \times 10^{-9} \mathrm{~mol} /$ $\mathrm{L}$ in infants and adults, respectively). However, the maximum binding capacity per unit of cell surface area was $25 \%$ increased in the infant group $\left(675\right.$ and $547 \mathrm{pmol} / \mu \mathrm{m}^{2} \times 10^{-13}$ in infants and adults respectively, $p<0.01)$.

\section{DISCUSSION}

The inhibition of lipolysis by endogenous substances, acting through different receptors coupled to adenylate cyclase, represents a potentially important mechanism for the regulation of lipolysis. At least four different receptors of this type are present in human fat cells: $\alpha_{2}$-adrenoceptors, $\mathrm{PGE}_{2}$, receptors, nicotinic acid receptors, and adenosine receptors $(5,6)$. Our study shows that stimulation of these four receptors leads to different patterns of antilipolytic activity in isolated fat cells of 1 - to 4-mo-old infants, as compared to 23- to 46-y-old adults. Adipocytes obtained from infants had a much higher antilipolytic sensitivity to clonidine than those from adults. This is in accordance with previous results from our laboratory that were recently obtained in other groups of subjects and with theophyllamine as lipolysis stimulator (3). Unlike clonidine, PIA had a 14 times lower antilipolytic potency (expressed as mean $\mathrm{ED}_{50}$ values) in infants than in adults. In this respect it is interesting to note that PIA seems more effective in inhibiting lipolysis in fat cells from older than in those from younger rats (19) and that 3T3-F442A preadipocytes during the differentiation to adipocytes change from the expression of stimulatory adenosine receptors to $G_{i}$ coupled inhibitory ones (20). In contrast to the findings with clonidine and PIA, the antilipolytic effects of nicotinic acid and PGE were not influenced by age.

It is well established that the $G_{i}$ protein plays a central role as mediator of inhibitory adenylate cyclase coupled receptors. In theory however, the antilipolytic effects of these agents may in part be mediated by mechanisms independent of $G_{i}$ and adenylate cyclase, e.g. through the phosphatidyl-inositol system $(21$, 22). However, when adipocytes were pretreated with PT, none of the inhibitors was antilipolytic which indicates that the major effect of the inhibitors on lipolysis is mediated through $G_{i}$ (or some other PT-sensitive $G$ protein) in infants as well as in adults.

The differences between infants and adults with respect to the antilipolytic effects of PIA and clonidine may have several explanations. They may be due to changes in the adenosine and $\alpha_{2^{-}}$ adrenergic receptors or in the interactions between these receptors and the GTP-sensitive coupling protein. They may also be due to alterations below the coupling protein in the cascade of events that leads to lipolysis. However, the antilipolytic sensitivities of PIA and clonidine were shifted in opposite directions in infants and adults, whereas no changes were observed with prostaglandin or nicotinic acid sensitivity. Furthermore, no changes in maximal antilipolytic effect were observed for any of the agents. this combination of observations can hardly be explained by an altered function in or below the $G_{i}$ protein. Instead, these data strongly suggest that the influence of age on the sensitivities to PIA and clonidine is due to changes in the adenosine and the $\alpha_{2}$-adrenergic receptors. Unfortunately, there is not yet any method developed for the measurement of adenosine receptors in minute amounts of isolated human fat cells. However, the binding site density for the $\alpha_{2}$-adrenoceptor antagonist $\left[{ }^{3} \mathrm{H}\right]$ yohimbine was significantly increased by $25 \%$ on adipocytes from infants as compared to those from adults. A major question is whether this rather small difference in receptor number may explain the larger differences in sensitivity (14-fold) between infants and adults. It has recently been reported from our laboratory that there is a nonlinear correlation between $\alpha_{2^{-}}$ adrenoceptor agonist binding and antilipolytic effects in human adult fat cells that seems to be due to the action of so-called spare receptors (23). In that study, a small reduction of the $\alpha_{2}$-adrenoceptor number resulted in a marked reduction of the clonidine sensitivity without any change in the maximal effect of clonidine. With those results in mind, it is reasonable to infer that the poor lipolytic effect of catecholamines during infancy, which previously has been shown to be a result of an enhanced $\alpha_{2}$-adrenoceptor sensitivity (3), may be due at least in part to the increased number of receptors. It is also possible that an age-dependent variation in the coupling between the receptor and $G_{i}$ may play an additional role.

Although inhibition of lipolysis mediated by adenylate cyclasecoupled receptors represents an effective way of modulating lipid mobilization from adipose tissue, little is known about the physiologic and pathophysiologic roles of this system in the regulation of lipolysis in man. Attenuated antilipolytic effects through adenosine receptors have been observed in the fat cells of obese subjects (24). A role of $\alpha_{2}$-adrenoceptors in the regulation of fatcell size in man has been suggested, because a negative relationship between antilipolytic effects of catecholamines and fat cell volume has been demonstrated both in normal conditions (15) and when catecholamine-induced lipolysis is altered, as in diabetes and starvation states (25). $\alpha_{2}$-Adrenoceptors may also play a role for the protection of the fat cells from deprivation during situations with catecholamine surge in the perinatal period (4). A reduced antilipolytic effect of $\mathrm{PGE}_{2}$ has also been reported in human fat cells in hyperthyroidism (26). Our study indicates that the antilipolytic receptors for catecholamines and adenosine, which presumably act through the same coupling proteins, can be regulated independently of each other and thus may have different roles in the regulation of lipolysis in man. The adipose tissue mass increases markedly during infancy, mainly because of a rapid increase in fat cell size. It is possible that the variations in the effects of catecholamines and adenosine during infancy are of importance for the regulation of fat cell size in this period of life.

Acknowledgments. The excellent technical assistance of Gunilla Micha and help from the staff on the Metabolic Ward at Huddinge Hospital are greatly appreciated. 


\section{REFERENCES}

1. Burns WT, Langley PE 1970 Lipolysis by human adipose tissue: the rate of cyclic $3^{\prime} 5^{\prime}$ adenosine, monophosphate and adrenergic receptor sites. J Lab Clin Med 75:983-987

2. Östman J, Efendic S 1970 Catecholamines and metabolism of human adipose tissue. II. Effect of isopropyl-noradrenaline and adrenergic blocking agent on lipolysis in human adipose tissue in vitro. Acta Med Scand 187:471-476

3. Marcus C, Karpe B, Bolme P, Sonnenfeld T, Arner P 1987 Changes in catecholamine-induced lipolysis in isolated human fat cells during the first year of life. J Clin Invest 79:1812-1818

4. Marcus C, Ehren H, Bolme P, Arner P 1988. Regulation of lipolysis at beginning of human life: Importance of thyrotropin. J Clin Invest 82:17931796

5. Davies JI, Saggerson JE 1981. The mechanisms of hormone and drug actions on fatty acid release from adipose tissue. Rev Pure Appl Pharmacol 2:1-112

6. Levitzki A 1984 Receptor to effector coupling in the receptor-dependent adenylate cyclase system. J Recept Res 4:399-409

7. Katada T, Ui M 1982 ADP ribosylation of the specific membrane protein of C6 cells by islet-activating protein associated with modification of adenylate cyclase activity. J Biol Chem 257:7210-7216

8. Björkman I, Arner P, Thore A, Östman J 1981 Sensitive kinetic bioluminescent assay of glycerol release from human fat cells. J Lipid Res 22:1147-1153

9. Engfeldt P, Arner P, Kimura H, Wahrenberg H, Östman J 1983. Determination of adrenoceptors of the alpha ${ }_{2}$-subtype on isolated human fat cells. Scand J Clin Invest 43:207-213

10. Rodbell M 1964. Metabolism of isolated fat cells. I. Effects of hormones on glucose metabolism and lipolysis. J Biol Chem 239:375-380

11. Arner P, Bolinder J, Östman J 1983 Glucose stimulation of the antilipolytic effect of insulin in humans. Science 220:1057-1059

12. Hirsch J, Gallian E 1968. Method for the determination of adipose cell size and cell number in man and animals. J Lipid Res 9:110-119

13. Zinder Z Shapiro B 1971. Effect of cell size on epinephrine and ACTH induced fatty acid release from isolated fat cells. J Lipid Res 9:110-119

14. Ohisalo J 1981 Effects of adenosine on lipolysis in human subcutaneous fat cells. J Clin Endocrinol Metab 52:359-363

15. Arner P, Marcus C, Karpe B, Sonnenfeld T, Bolme P 1986 Role of alphaadrenoceptors for adipocyte size in man. Eur J Clin Invest 17:58-62

16. Kather H 1988. Purine accumulation in human fat cell suspensions: evidence that human adipocytes release inosine and hypoxanthine rather than adenosine. J Biol Chem 263:8803-8809.

17. Kather H, Bieger W, Michel G, Aktories K, Jakobs KH 1985 Human fat cell lipolysis is primarily regulated by inhibitory modulators acting through distinct mechanisms. J Clin Invest 76:1559-1565

18. Scatchard G 1949. The attractions of proteins for small molecules and ions. Ann NY Acad Sci 51:660-672

19. Hoffman BB, Chang H, Farahbakhsh Z, Reaven G 1984. Inhibition of lipolysis by adenosine is potentiated with age. J Clin Invest 74:1750-1755

20. Ravid $\mathrm{K}$, Lowenstein $\mathbf{J} 1988$. Changes in adenosine receptors during differentiation of 3T3-F442A cells to adipocytes. Biochemical J 249:377-381

21. Doctrow SR, Lowenstein JM 1985 Adenosine and 5'-chloro-5'-deoxyadenosine inhibit the phosphorylation of phosphatidyl-inositol and myosin lightchain in calf aorta smooth muscle. J Biol Chem 260:3469-3476

22. Schimmel RJ, McCarthy L 1986. Effects of insulin, adenosine and prostaglandin on alpha-adrenergic-stimulated respiration in brown adipocytes. Am J Physiol 250:C738-C743

23. Arner P, Hellmér J, Wennlund A, Östman J, Engfeldt P 1988 Adrenoceptor occupancy in isolated fat cells and its relationship with lipolysis rate. Eur $\mathrm{J}$ Pharmacol 146:45-56

24. Ohisalo JJ, Ranta S, Huhtaniemi IT 1986. Attenuated adenosine R-site effect in adipocytes in obesity. Metabolism 35:143-146.

25. Arner P, Engfeldt P, Östman J 1979. Relationship between lipolysis, cyclic AMP, and fat-cell size in human adipose tissue during fasting and in diabetes mellitus. Metabolism 28:198-209.

26. Richelsen B, Pedersen O, Schwartz Sörensen N 1986. Reduced binding and antilipolytic effect of prostaglandin $E_{2}$ in adipocytes from patients with hyperthyroidism. J Clin Endocrinol Metab 62:258-262. 